\title{
HUBUNGAN ANTARA KEMAMPUAN GURU DALAM MELAKUKAN PENGELOLAAN LINGKUNGAN BELAJAR DENGAN MOTIVASI BELAJAR ANAK USIA DINI
}

\author{
Azmi Noor Ramdhayani, Mubiar Agustin, Rita Mariyana \\ Universitas Pendidikan Indonesia, Jln. Setiabudhi no. 229 Bandung \\ e-mail: azminramadhayani@yahoo.co.id
}

\begin{abstract}
Abstrak : The Relationship Between the Ability of Teachers in Managing the Learning Environment to Early Childhood Learning Motivation. This study aims to determine the relationship between the ability of teachers in managing the learning environment to early childhood learning motivation. This research using correlational. The study subjects were 13 teachers. Data collection techniques in this research thorough a questionnaire containing the ability of techers in managing the laerning environment and a questionnaire about the child's learning motivation. The data analisys technique used quantitative desciptive data analysis with several stages including the validation peocess, realibilitas, correlation analysis and conclusion. The results showed a 100\% ability of techers in managing the learning environment in both categories. Both the magnitude of correlation 0,584 so it can be concluded there is a positive relationship between the ability of teachers in managing the learning environment to the children's learning motivation. Recommendations given to teachers, teachers are expected to further enhance their ability to manage the learning environment because it is not directly the ability of techers in managing the learning environment influence the creation of early childhood's learning motivation.
\end{abstract}

Keywords: the ability of teachers in managing the learning environment, early childhood learning motivation.

Abstrak: Hubungan Antara Kemampuan Guru dalam Melakukan
Pengelolaan Lingkungan Belajar dengan Motivasi Belajar Anak Usia Dini. Penelitian ini bertujuan untuk mengetahui hubungan antara kemampuan guru dalam melakukan pengelolaan lingkungan belajar dengan motivasi belajar anak usia dini. penelitian ini menggunakan metode korelasional. Subjek penelitian berjumlah 13 orang guru. Teknik pengumpulan data dalam penelitian ini, yaitu melalui angket yang berisi kemampuan guru dalam melakukan pengelolaan lingkungan belajar dan angket mengenai motivasi belajar anak. teknik analisis data yang digunakan adalah analisis data deskriptif kuantitatif dengan beberapa tahapan diantaranya adalah proses validasi, reliabilitas, analisis korelasi, dan penarikan kesimpulan. Hasil penelitian menunjukkan 100\% kemampuan guru dalam melakukan pengelolaan lingkungan belajar dalam kategori baik, dan $100 \%$ motivasi belajar anak usia dini dalam kategori baik. Besarnya korelasi keduanya yaitu sebesar 0,854 sehingga dapat disimpulkan terdapat hubungan yang positif antara kemampuan guru dalam melakukan pengelolaan lingkungan belajar dengan motivasi belajar anak. Rekomendasi yang diberikan untuk guru yaitu guru diharapkan lebih meningkatkan lagi kemampuan guru dalam melakukan pengelolaan lingkungan belajar karena secara tidak langsung kemampuan guru dalam melakukan pengelolaan lingkungan belajar ikut mempengaruhi terciptanya motivasi belajar anak. 
Kata Kunci: kemampuan guru dalam melakukan pengelolaan lingkungan belajar, motivasi belajar anak

Periode usia TK adalah masa peka. Anak sensitif untuk menerima segala rangsangan, yaitu pada masa fungsi-fungsi fisik dan psikis telah siap merespon segala rangsangan (stimulus) yang diberikan oleh lingkungan. Dengan demikian, lingkungan sebagai unsur yang mensuplai atau menyediakan sejumlah rangsangan perlu mendapat perhatian sungguh-sungguh. Diperlukan perencanaan dan seleksi khusus agar dapat menyediakan lingkungan yang cocok dan diperlukan anak. ketepatan lingkungan yang disediakan akan memberi pengaruh pada proses dan hasil perilaku anak, baik secara langsung maupun tidak langsung.

Merujuk pada pendapat Sujiono, Y.N. (2009). Konsep Dasar Pendidikan Anak Usia Dini, Sebagai makhluk hidup, anak selain berinteraksi dengan orang atau manusia lain juga berinteraksi dengan sejumlah makhluk hidup lainnya dan bendabenda mati. Makhluk hidup tersebut antara lain adalah berbagai tumbuhan dan hewan, sedangkan benda-benda mati antara lain udara, air, dan tanah. Manusia merupakan salah satu anggota di dalam lingkungan hidup yang berperan penting dalam kelangsungan jalinan hubungan yang terdapat dalam sistem tersebut.

Merujuk pada pendapat Vora, Adelia (2011) Metode Mengajar Anak Dalam Kelas, Pengertian Menata Lingkungan Belajar Menata lingkungan belajar pada hakekatnya melakukan pengelolaan lingkungan belajar. Aktivitas guru dalam menata lingkungan belajar lebih terkonsentrasi pada pengelolaan lingkungan belajar di dalam kelas. Merujuk pendapat dari Fadlillah, Muhammad (2014) Desain Pembelajaran PAUD, Pengelolaan lingkungan belajar yang baik akan melahirkan interaksi belajar mengajar yang baik pula. Tujuan pembelajaran pun dapat dicapai tanpa menemukan kendala yang berarti. Dengan tercapainya tujuan pembelajaran, maka dapat dikatakan bahwa guru telah berhasil dalam mengajar.

Selain motivasi dalam hal ini juga menekankan bahwa kompetensi guru sangat diperlukan. Kompetensi meliputi seluruh kemampuan guru yang berfungsi sebagai penunjang dalam proses pembeajaran sehingga mampu memberikan dampak positif terhadap peserta didik..

Merujuk hasil dari penelitian yang di lakukan peneliti di beberapa TK di Cimahi selatan, peneliti menemukan bahwa terdapat motivasi dan minat belajar para siswa yang tinggi di beberapa TK yang pengajarnya mampu mengelola lingkungan belajar dengan baik, dan juga ditemukan bahwa tidak semua guru TK dapat melakukan hal itu di beberapa TK di cimahi selatan, oleh karena itu sangatlah penting kemampuan guru dalam melakukan pengelolaan lingkungan belajar agar iklim belajar dan motivasi belajar menajdi lebih optimal..

\section{METODE}

Penelitian ini bertujuan untuk membuat deskripsi, gambaran secara sistematis, faktual dan akurat mengenai fakta-fakta, sifat-sifat serta hubungan fenomena antara kemampuan guru dalam melakukan pengelolaan lingkungan belajar dengan motivasi belajar anak. dengan teknik 
analisis yang digunakan yaitu uji statistik Korelasional Person Product Moment.

adapun melalui survei berupa pertanyaan tertulis dan tes, untuk mengumpulkan informasi, mengidentifikasi dan menentukan persepsi, dan pendapat dari responden survei, yaitu guru TK di kota Cimahi selatan, dan akan di jabarkan kedalam beberapa komponen masalah dengan teknik yang digunakan untuk pengumpulan data tersebut adalah teknik angket. Setiap pernyataan memiliki pilihan jawaban Ya atau Tidak. Pemberian skor pada jawaban sampel penelitian diberi bobot nilai 0 hingga 1 yang disesuaikan dengan kriteria penskoran yang ditunjukkan pada tabel berikut:

\section{Tabel 1. Kriteria skor instrumen}

\begin{tabular}{ccc}
\hline $\begin{array}{c}\text { Pilihan } \\
\text { Jawaban }\end{array}$ & $\begin{array}{c}\text { Pernyataan } \\
\text { Positif }\end{array}$ & $\begin{array}{c}\text { Pernyataan } \\
\text { Negatif }\end{array}$ \\
\hline Ya & 1 & 0 \\
\hline Tidak & 0 & 1 \\
\hline
\end{tabular}

Analisis data merupakan kegiatan yang dilakukan setelah data dari seluruh responden atau sumber data lain terkumpul. Teknik analisis data penelitian ini dilihat berdasarkan hasil ujinnormalitas.

a. Uji Normalitas

uji normalitas data dengan menggunakan software SPSS versi 20.0.

b. Uji Korelasi

uji korelasi antara kemampuan guru dalam mengelola lingkungan belajar drngan motivasi belajar anak adalah sebagai berikut :

1) Menghitung Korelasi dengan rumus sebagai berikut :

$$
r_{x y}=\frac{N \sum X Y-\left(\sum X\right)\left(\sum Y\right)}{\sqrt{\left\{N \sum X^{2}-\left(\sum X\right)^{2}\right\}\left\{N \sum Y^{2}-\left(\sum Y\right)^{2}\right\}}}
$$

(Arikunto, 2002:72)
Keterangan:

$r_{x y}=$ Koefisien korelasi antara variabel $\mathrm{X}$ dan variabel $\mathrm{Y}$

$X=$ Item soal yang dicari validitasnya

$Y=$ Skor total yang diperoleh sampel

2) Menguji Hipotesis

$\mathrm{H}_{\mathrm{o}}$ : Tidak ada hubungan (Korelasi) antara kemampuan guru dalam melakukan pengelolaan lingkungan belajar dan motivasi belajar anak usia dini

$\mathrm{H}_{\mathrm{i}}$ : Ada hubungan (Korelasi) antara kemampuan guru dalam melakukanpengelolaan lingkungan belajar dan motivasi belajar anak usia dini

3) Dasar pengambilan keputusan Jika nilai sig $>0,05$ maka $\mathrm{H}_{\mathrm{o}}$ diterima

Jika nilai sig $<0,05$ maka $\mathrm{H}_{\mathrm{o}}$ ditolak

4) Pengambilan keputusan

Keputusan diterima atau ditolak.

5) Analisis Koefisien Determinasi

$\mathrm{KD}=r^{2} \times 100 \%$

Keterangan:

$\mathrm{KD}=$ Koefisien determinasi yang dicari

$r^{2}=$ Kuadrat koefisien korelasi

\section{HASIL DAN PEMBAHASAN}

Profil Kemampuan Guru dalam Melakukan Pengelolaan Lingkungan Belajar

Hasil penelitian menunjukan bahwa kemampuan guru dalam melakukan pengelolaan lingkungan belajar berada di kategori baik atau $100 \%$ kemampuan guru dalam pengelolaan lingkungan belajar berada pada kategori baik. Berikut tabel 2 menyajikan secara lengkap profil 
kemampuan guru dalam pengelolaan lingkungan belajar.

Tabel 2. Profil Kemampuan Guru dalam Melakukan Pengelolaan Lingkungan Belajar

\begin{tabular}{llll}
\hline Kriteria & Interval & Frekuensi & Persentase \\
\hline Baik & $55-65$ & 13 & $100 \%$ \\
\hline $\begin{array}{l}\text { Cukup } \\
\text { Baik }\end{array}$ & $32-54$ & 0 & $0 \%$ \\
\hline $\begin{array}{l}\text { Kurang } \\
\text { Baik }\end{array}$ & $9-31$ & 0 & $0 \%$ \\
\hline Jumlah & & 13 & $100 \%$ \\
\hline
\end{tabular}

Bila digambarkan dalam bentuk grafik, maka Profil Kemampuan Guru dalam Melakukan Pengelolaan Lingkungan Belajar tersaji dalam Grafik 1 berikut :

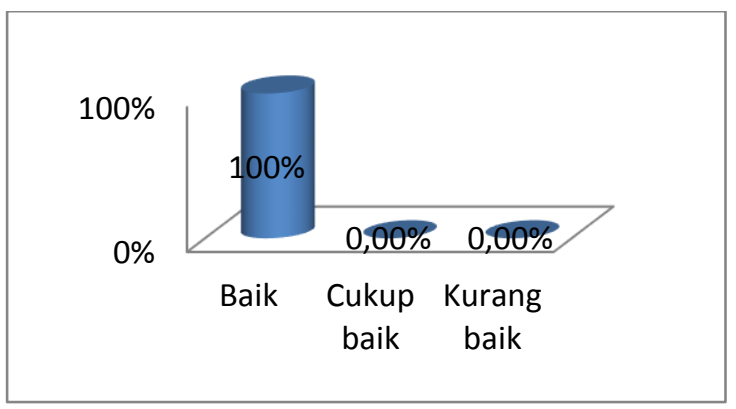

\section{Grafik 1. Profil Kemampuan Guru dalam Melakukan Pengelolaan Lingkungan Belajar}

Selanjutnya, jika Profil Kemampuan Guru dalam Melakukan Pengelolaan Lingkungan Belajar diuraikan berdasarkan sub variabelnya, maka tersaji seperti pada Tabel 2 berikut :

Tabel 2. Profil Kemampuan Guru dalam Melakukan Pengelolaan Lingkungan Belajar

\begin{tabular}{|c|c|c|c|c|c|}
\hline $\begin{array}{l}\mathrm{N} \\
\mathrm{O}\end{array}$ & $\begin{array}{c}\text { Sub } \\
\text { Variabel }\end{array}$ & Kriteria & $\begin{array}{c}\text { Inter } \\
\text { val }\end{array}$ & $\begin{array}{c}\text { Freku } \\
\text { ensi }\end{array}$ & $\begin{array}{l}\text { Persenta } \\
\text { se }\end{array}$ \\
\hline \multirow[t]{3}{*}{1} & $\begin{array}{l}\text { Mewujud } \\
\text { kan }\end{array}$ & Baik & $\begin{array}{c}18- \\
26\end{array}$ & 11 & $96,23 \%$ \\
\hline & \multirow{2}{*}{$\begin{array}{l}\text { suasana } \\
\text { belajar } \\
\text { yang } \\
\text { efektif }\end{array}$} & $\begin{array}{l}\text { Cukup } \\
\text { baik }\end{array}$ & $\begin{array}{l}9- \\
17\end{array}$ & 2 & $3,77 \%$ \\
\hline & & $\begin{array}{c}\text { Kurang } \\
\text { baik }\end{array}$ & $0-8$ & 0 & $0,00 \%$ \\
\hline $\begin{array}{l}\mathrm{N} \\
\mathrm{O}\end{array}$ & $\begin{array}{c}\text { Sub } \\
\text { Variabel }\end{array}$ & Kriteria & $\begin{array}{c}\text { Inter } \\
\text { val }\end{array}$ & $\begin{array}{c}\text { Freku } \\
\text { ensi }\end{array}$ & $\begin{array}{c}\text { Persenta } \\
\text { se }\end{array}$ \\
\hline \multirow[t]{3}{*}{2} & \multirow{3}{*}{$\begin{array}{l}\text { Penataan } \\
\text { ruangan } \\
\text { belajar }\end{array}$} & Baik & $\begin{array}{c}16- \\
23\end{array}$ & 9 & $92,57 \%$ \\
\hline & & $\begin{array}{l}\text { Cukup } \\
\text { baik }\end{array}$ & $\begin{array}{l}8- \\
15\end{array}$ & 4 & $7,43 \%$ \\
\hline & & $\begin{array}{c}\text { Kurang } \\
\text { baik }\end{array}$ & $0-7$ & 0 & $0,00 \%$ \\
\hline \multirow{3}{*}{3} & \multirow{3}{*}{$\begin{array}{l}\text { Pemeliha } \\
\text { raan ke- } \\
\text { bersihan } \\
\text { lingkung } \\
\text {-an } \\
\text { belajar }\end{array}$} & Baik & $6-7$ & 12 & $98,11 \%$ \\
\hline & & $\begin{array}{l}\text { Cukup } \\
\text { baik }\end{array}$ & $3-5$ & 1 & $1,89 \%$ \\
\hline & & $\begin{array}{c}\text { Kurang } \\
\text { baik }\end{array}$ & $0-2$ & 0 & $0,00 \%$ \\
\hline \multirow{3}{*}{4} & \multirow{3}{*}{$\begin{array}{l}\text { Memper- } \\
\text { siapkan } \\
\text { perleng- } \\
\text { kapan } \\
\text { aktifitas } \\
\text { belajar }\end{array}$} & Baik & $8-9$ & 10 & $94,35 \%$ \\
\hline & & $\begin{array}{l}\text { Cukup } \\
\text { baik }\end{array}$ & $4-7$ & 3 & $5,65 \%$ \\
\hline & & $\begin{array}{c}\text { Kurang } \\
\text { baik }\end{array}$ & $0-3$ & 0 & $0.00 \%$ \\
\hline
\end{tabular}

Berdasarkan Tabel 2 diperoleh bahwa pada sub variabel 1 (Mewujudkan suasana belajar yang efektif) 3,77\% guru berada pada kategori cukup baik dan 96,23\% guru berada dikategori baik. Pada sub variabel 2 (Penataan ruangan belajar) $7,43 \%$ guru berada pada kategori cukup baik dan 92,57\% guru berada dikategori baik. Pada sub variabel 3 (Pemeliharaan kebersihan lingkungan belajar) 1,89\% guru berada pada kategori cukup baik dan 98,11\% guru berada dikategori baik. Pada sub variabel 4 (Mempersiapkan perlengkapan aktifitas belajar) $5,65 \%$ guru berada pada kategori cukup baik dan $94,35 \%$ guru berada dikategori baik.

\section{Profil Motivasi Belajar Anak Usia Dini}

Hasil penelitian menunjukan bahwa motivasi belajar anak usia dini berada di kategori baik atau $100 \%$ motivasi belajar 
anak usia dini berada pada kategori baik. Berikut tabel 3 menyajikan secara lengkap profil motivasi belajar anak usia dini tersebut :

Tabel 3. Profil Motivasi Belajar Anak Usia Dini

\begin{tabular}{cccc}
\hline Kriteria & Interval & Frekuensi & Persentase \\
\hline Baik & $29-39$ & 13 & $100 \%$ \\
\hline $\begin{array}{c}\text { Cukup } \\
\text { Baik }\end{array}$ & $22-28$ & 0 & $0 \%$ \\
\hline $\begin{array}{c}\text { Kurang } \\
\text { Baik }\end{array}$ & $15-21$ & 0 & $0 \%$ \\
\hline \multicolumn{2}{c}{ Jumlah } & 13 & $100 \%$ \\
\hline
\end{tabular}

Bila digambarkan dalam bentuk grafik, maka Profil Motivasi BelajarAnak Usia Dini tersaji dalam Grafik 2 berikut :

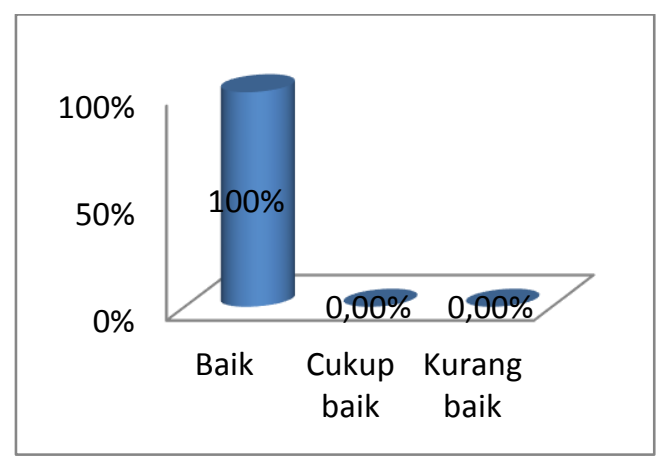

\section{Grafik 2. Profil Motivasi Belajar Anak Usia Dini}

Selanjutnya, jika Profil Kemampuan Guru dalam Melakukan Pengelolaan Lingkungan Belajar diuraikan berdasarkan sub variabelnya, maka tersaji seperti pada Tabel 4 berikut :

Tabel 4. Profil Motivasi Belajar Anak Usia Dini

\begin{tabular}{cccccc}
\hline $\begin{array}{c}\mathrm{N} \\
\mathrm{o}\end{array}$ & $\begin{array}{c}\text { Sub } \\
\text { Variabel }\end{array}$ & Kiteria & $\begin{array}{c}\text { Inter } \\
\text { val }\end{array}$ & $\begin{array}{c}\text { Freku } \\
\text { ensi }\end{array}$ & $\begin{array}{c}\text { Persenta } \\
\text { se }\end{array}$ \\
\hline \multirow{2}{*}{1} & Faktor & Baik & $12-$ & 10 & $\begin{array}{c}94,35 \\
\%\end{array}$ \\
\cline { 3 - 6 } & sosial & & 16 & & $5,65 \%$ \\
\hline
\end{tabular}

\begin{tabular}{llcccc}
\hline & & & & \\
\hline & & baik & 11 & & \\
\cline { 2 - 5 } 2 & $\begin{array}{l}\text { Kuran } \\
\text { g baik }\end{array}$ & $0-5$ & 0 & $0.00 \%$ \\
\hline \multirow{2}{*}{$\begin{array}{l}\text { lingkung } \\
\text { an }\end{array}$} & Baik & $6-7$ & 11 & $\begin{array}{c}96,23 \\
\%\end{array}$ \\
\cline { 2 - 5 } & $\begin{array}{l}\text { Cukup } \\
\text { baik }\end{array}$ & $3-5$ & 2 & $3,77 \%$ \\
\cline { 2 - 5 } & $\begin{array}{l}\text { Kuran } \\
\text { g baik }\end{array}$ & $0-2$ & 0 & $0.00 \%$ \\
\hline
\end{tabular}

Berdasarkan Tabel 4. diperoleh bahwa pada sub variabel 1 (Faktor sosial) 5,65\% anak berada pada kategori cukup baik dan 94,35\% anak berada dikategori baik. Pada sub variabel 2 (Fakto lingkungan) 3,77\% anak berada pada kategori cukup baik dan 96,23\% guru berada dikategori baik. Pada sub variabel 3 (Faktor keluarga) 1,89\% anakberada pada kategori cukup baik dan $98,11 \%$ anak berada dikategori baik.

Hubungan antara Kemampuan Guru Dalam Melakukan Pengelolaan Lingkungan Belajar Dengan Motivasi Belajar Anak Usia Dini Di Kota Cimahi Selatan

Hasil dari hubungan antara Kemampuan Guru Dalam Melakukan Pengelolaan Lingkungan Belajar Dengan Motivasi Belajar Anak Usia Dini Di Kota Cimahi Selatan disajikan pada Tabel 5 berikut :

Tabel 5. Hubungan Kemampuan Guru Dalam Melakukan Pengelolaan Lingkungan Belajar Dengan Motivasi Belajar Anak Usia Dini Di Kota Cimahi Selatan

\begin{tabular}{|c|c|c|c|}
\hline & & $\begin{array}{c}\text { Kemam- } \\
\text { puan Guru } \\
\text { Dalam } \\
\text { Melakukan } \\
\text { Pengelola- } \\
\text { an Ling- } \\
\text { kungan } \\
\text { Belajar } \\
\end{array}$ & $\begin{array}{c}\text { Motivasi } \\
\text { Belajar } \\
\text { Anak } \\
\text { Usia } \\
\text { Dini }\end{array}$ \\
\hline \multirow{2}{*}{$\begin{array}{l}\text { Kemam- } \\
\text { puan Guru } \\
\text { Dalam } \\
\text { Melaku- } \\
\text { kan }\end{array}$} & $\begin{array}{l}\text { Pearson } \\
\text { Correlat } \\
\text { ion }\end{array}$ & 1 &, $854 * *$ \\
\hline & $\begin{array}{l}\text { Sig (2 } \\
\text { tailed) }\end{array}$ & & ,000 \\
\hline
\end{tabular}




\begin{tabular}{|c|c|c|c|}
\hline $\begin{array}{l}\text { Pengelola } \\
\text { an Ling- } \\
\text { kungan } \\
\text { Belajar }\end{array}$ & $\mathrm{N}$ & 13 & 13 \\
\hline \multirow{4}{*}{$\begin{array}{l}\text { Motivasi } \\
\text { Belajar } \\
\text { Anak Usia } \\
\text { Dini }\end{array}$} & Pearson & ,854** & 1 \\
\hline & $\begin{array}{l}\text { Correlat } \\
\text { ion }\end{array}$ & & \\
\hline & $\begin{array}{l}\text { Sig }(2 \\
\text { tailed) }\end{array}$ &, 000 & \\
\hline & $\mathrm{N}$ & 13 & 13 \\
\hline
\end{tabular}

Tahapan uji korelasi antara kemampuan guru dalam melakukan pengelolaan lingkungan belajar dengan motivasi belajar anak usia dini di kota Cimahi Selatan adalah sebagai berikut:

a. Hipotesis

Ho: Tidak ada hubungan (korelasi) antara kemampuan guru dalam melakukan pengelolaan lingkungan belajar dengan motivasi belajar anak usia dini di kota Cimahi Selatan

Hi: Ada hubungan (korelasi) kemampuan guru dalam melakukan pengelolaan lingkungan belajar dengan motivasi belajar anak usia dini di kota Cimahi Selatan

b. Dasar Pengambilan Keputusan

Jika nilai sig > 0,05 maka $\mathrm{H}_{0}$ diterima Jika nilai sig $<0,05$ maka $\mathrm{H}_{0}$ ditolak

c. Pengambilan Keputusan

Karena nilai sig $=0,000$ lebih kecil dari 0,05 maka dapat disimpulkan bahwa $\mathrm{H}_{0}$ ditolak dan $\mathrm{H}_{\mathrm{a}}$ diterima. Atau dengan kata lain dapat disimpulkan bahwa terdapat hubungan (korelasi) yang signifikan antara Kemampuan Guru Dalam Melakukan Penglolaan Lingkungan Belajar Dengan Motivasi Anak Usia Dini di Kota Cimahi Selatan. Besarnya korelasi tersebut adalah 0,854. Hal ini menunjukkan bahwa semakin tinggi Kemampuan Guru Dalam Melakukan Penglolaan Lingkungan Belajar semakin tinggi Motivasi Belajar
Anak Usia Dini dan sebaliknya jika semakin rendah Kemampuan Guru Dalam Melakukan Penglolaan Lingkungan Belajar semakin rendah pula Motivasi Belajar Anak Usia Dini. Hasil pengujian hipotesis di atas dapat ditunjang oleh pemaparan secara deskriptif mengenai penyebaran responden berdasarkan Kemampuan Guru Dalam Melakukan Penglolaan Lingkungan Belajar dan Motivasi Anak Usia Dini seperti terlihat pada Tabel 6 berikut:

Tabel 6. Motivasi Belajar Anak Usia Dini berdasarkan Kemampuan Guru dalam Melakukan Pengelolaan IIngkungan Belajar

\begin{tabular}{ccccc}
\hline $\begin{array}{c}\text { Kemampuan } \\
\text { Guru dalam } \\
\begin{array}{c}\text { Melakukan } \\
\text { Pengelolaan }\end{array}\end{array}$ & $\begin{array}{c}\text { Motivasi Belajar Anak } \\
\text { Usia Dini }\end{array}$ & $\begin{array}{c}\text { Jum- } \\
\text { lah }\end{array}$ \\
\cline { 2 - 4 } $\begin{array}{c}\text { Ingkungan } \\
\text { Belajar }\end{array}$ & & Cukup & Kurang nn & \\
\hline Baik & 13 & 0 & 0 & 13 \\
\hline Cukup Baik & 0 & 0 & 0 & 0 \\
\hline Kurang Baik & 0 & 0 & 0 & 0 \\
\hline Jumlah & 13 & 0 & 0 & 13 \\
\hline
\end{tabular}

Berdasarkan hasil data perhitungan di atas, analisis koefisien determinasi dilakukan untuk mengetahui seberapa besar kontribusi yang diberikan oleh kedua variabel, yaitu variabel kemampuan guru dalam melakukan pengelolaan lingkungan belajar dengan motivasi belajar anak usia dini,. Besarnya koefisien determinasi data kemampuan guru dalam melakukan pengelolaan lingkungan belajar dengan motivasi belajar anak usia dini adalah sebagai berikut:

$$
\begin{aligned}
\mathrm{KD} & =\mathrm{r}^{2} \times 100 \% \\
& =(0,854)^{2} \times 100 \% \\
& =0,729316 \times 100 \% \\
& =72,93 \%
\end{aligned}
$$


Berdasarkan perhitungan di atas, maka dapat disimpulkan bahwa kemampuan guru dalam melakukan pengelolaan lingkungan belajar memberikan kontribusi sebesar 72,93 $\%$ terhadap motivasi belajar anak usia dini, sedangkan 27,07\% motivasi belajar anak usia dini dipengaruhi oleh variabel lain yang tidak diteliti oleh penulis.

Adapun pembahasan dari hasil penelitian Kemampuan Guru dalam Melakukan Pengelolaan Lingkungan Belajar dengan Motivasi Belajar Anak Usia Dini di Kota Cimahi Selatan adalah sebagai berkut :

\section{Profil Kemampuan Guru dalam Melakukan Pengelolaan Lingkungan Belajar dengan Motivasi Belajar Anak Usia Dini di Kota Cimahi Selatan}

Merujuk dari Rahmawati, Rita \& Ali (2010) Pengelolaan Lingkungan Belajar, Setelah melakukan penelitian didapatkan Kemampuan Guru dalam Melakukan Pengelolaan Lingkungan Belajar berada di interval skor 55-65, sehingga dapat dikatakan Kemampuan guru dalam melakukan pengelolaan lingkungan belajar $100 \%$ dalam keadaan baik. Adapun pembahasan hasil penelitian per sub variabelnya adalah sebagai berikut :

Mewujudkan suasana belajar yang efektif. Merujuk dari pendapat Rahmawati, Rita \& Ali (2010) Pengelolaan Lingkungan Belajar, Seorang guru taman kanak-kanak hendaknya mampu mewujudkan suasana belajar yang efekti dan menyenangkan.

Penataan ruangan belajar. Merujuk dari pendapat Rahmawati, Rita \& Ali (2010) Pengelolaan Lingkungan Belajar, Hasil penelitian menunjukan bahwa guru taman kanak-kanak di kota cimahi selatan sebagian besar mampu melakukan penataan ruangan belajar.

Pemeliharaan kebersihan lingkungan belajar. Merujuk dari pendapat Rahmawati, Rita \& Ali (2010) Pengelolaan Lingkungan Belajar, Hasil penelitian menunjukan bahwa guru taman kanak-kanak di kota cimahi selatan sebagian besar mampu melakukan pemeliharaan kebersihan lingkungan belajar.

Mempersiapkan perlengkapan aktifitas belajar. Merujuk dari pendapat Rahmawati, Rita \& Ali (2010) Pengelolaan Lingkungan Belajar, Berdasarkan hasil penelitian, data menunjukan bahwa guru taman kanak-kanak di kota cimahi selatan sebagian besar mampu mempersiapkan perlengkapan aktifitas belajar.

\section{Profil Motivasi Belajar Anak Usia Dini di Kota Cimahi Selatan.}

Hasil penelitian menunjukan bahwa motivasi belajar anak usia dini di kota cimahi selatan, 13 guru berada pada kategori cukup, dengan interval skor 29-39 sehingga dapat dikatakan Motivasi belajar anak usia dini $100 \%$ dalam keadaan baik. Ada beberapa factor dari hasil penelitian adalah sebagai berikut :

a. Faktor sosial.

b. Faktor lingkungan

c. Faktor keluarga

\section{Hubungan Antara Kemampuan Guru Dalam Melakukan Pengelolaan Lingkungan Belajar Dengan Motivasi Belajar Anak Usia Dini}

Berdasarkan hasil penelitian menunjukkan bahwa terdapat hubungan (korelasi) yang signifikan antara Kemampuan Guru Dalam Melakukan 
Pengelolaan Lingkungan Belajar dengan Motivasi Belajar Anak Usia Dini, Besarnya korelasi adalah sebesar 0,854. Hal ini dibuktikan dengan hasil perhitungan karena nilai sig $=0,000$ lebih kecil dari 0,05 maka $\mathrm{H}_{0}$ ditolak dan $\mathrm{H}_{\mathrm{a}}$ diterima, dengan demikian antara kedua variabel terdapat hubungan (korelasi) yang signifikan antara Kemampuan Guru Dalam Melakukan Pengelolaan Lingkungan Belajar dengan Motivasi Belajar Anak Usia Dini . Hal ini pun didukung oleh koefisien determinasi bahwa kemampuan guru dalam melakukan pengelolaan lingkungan belajar memberikan kontribusi sebesar 72,93 \% terhadap motivasi belajar anak usia dini, sedangkan 27,07\% motivasi belajar anak usia dini dipengaruhi oleh variabel lain yang tidak diteliti oleh penulis.

Hal ini menunjukan bahwa kemampuan guru dalam melakukan pengelolaan lingkungan belajar secara tidak langsung mempengarui motivasi belajar anak usia dini, sesuai yang dijelaskan oleh Rita Maryana, (2010) pada bab II, yaitu lingkungan dapat mendukung perkembangan intelektual yang lebih mantap.

\section{SIMPULAN}

Berdasarkan hasil penelitian dan pembahasan mengenai hubungan antara kemampuan guru dalam melakukan pengelolaan lingkungan belajar dengan motivasi belajar anak usia dini di Kota Cimahi Selatan, ditarik simpulan sebagai berikut :

Kemampuan Guru dalam Melakukan Pengelolaan Lingkungan Belajar di Kota Cimahi Selatan dapat dikatan baik, dimana implementasi kemampuan guru dalam melakukan pengelolaan lingkungan belajar telah terlaksana dengan baik karena di dukung oleh sarana dan prasarana serta fasilitas belajar yang memadai ,tetapi perlu di sempurnakan.

Merujuk pada hasil penelitian Nilai sig $=0,000$ lebih kecil dari 0,05 maka dapat disimpulkan bahwa $\mathrm{H}_{0}$ ditolak dan $\mathrm{H}_{\mathrm{a}}$ diterima. Disimpulkan bahwa terdapat hubungan (korelasi) yang signifikan antara Kemampuan Guru dalam Melakukan Pengelolaan Lingkungan Belajar dengan Motivasi Belajar Anak Usia Dini di Kota Cimahi Selatan Besarnya korelasi tersebut adalah 0,855. Hal ini menunjukkan bahwa semakin tinggi Kemampuan Guru dalam Melakukan Pengelolaan Lingkungan Belajar, maka Motivasi Belajar Anak Usia Dini semakin tinggi. kemampuan guru dalam melakukan pengelolaan lingkungan belajar memberikan kontribusi sebesar 72,93 $\%$ terhadap motivasi belajar anak usia dini, sedangkan 27,07\% motivasi belajar anak usia dini dipengaruhi oleh variabel lain yang tidak diteliti oleh penulis.

\section{DAFTAR PUSTAKA}

Arikunto, S. 2002. Prosedur Suatu Penelitian: Pendekatan Praktek. Edisi Revisi Kelima. Penerbit Rineka Cipta. Jakarta.

Fadlillah, Muhammad (2014) Desain Pembelajaran PAUD, Yogyakarta : Aruzz-Media.

Rahmawati, Yeni, Mariyana, Rita \& Nugraha, Ali (2010) Pengelolaan Lingkungan Belajar. Jakarta : Prenada Media

Sujiono, Y.N. (2009). Konsep Dasar Pendidikan Anak Usia Dini. Jakarta. Indeks.

Vora, Adelia (2011) Metode Mengajar Anak Dalam Kelas. Jakarta : Erlangga 